\title{
Effect of increasing densities of Urochloa brizantha cv. Marandu on Eucalyptus urograndis initial development in silvopastoral system
}

\author{
Michel Anderson Almeida Colmanetti ${ }^{1}$ - Allan Lopes Bacha ${ }^{2}$. \\ Pedro Luis da Costa Aguiar Alves ${ }^{2}$. Rinaldo Cesar de Paula ${ }^{2}$
}

Received: 4 May 2017/Accepted: 18 July 2017/Published online: 31 March 2018

(C) Northeast Forestry University and Springer-Verlag GmbH Germany, part of Springer Nature 2018

\begin{abstract}
In silvopasture system, the coexistence of eucalyptus seedlings with other species may result in growth reduction, especially during eucalyptus early development. Therefore, studies elucidating how forage species affect the eucalyptus growth can provide important information for their rational management aiming to obtain the maximum gain of the system. The aim of this work was to evaluate the effect of increasing densities of Urochloa brizantha $\mathrm{cv}$. Marandu in the early development of Eucalyptus urograndis. An experiment was conducted in $20 \mathrm{~L}$ pots, in an open and semi-controlled area, during 90 days after planting of eucalyptus. A completely randomized design with four replications was used, in a $6 \times 7$ factorial system, meaning six evaluation periods and seven densities of $U$. brizantha: 0 (control), 22, 33, 44, 67, 89 and 111 plants $\mathrm{m}^{-2}$. Fortnightly, eucalyptus height, stem diameter and chlorophyll fluorescence $\left(F_{\mathrm{v}} / F_{\mathrm{m}}\right)$ were evaluated. At the end of experimental period, the net assimilation rate, stomatal conductance and transpiration rate of eucalyptus plants were determined, in addition to the dry matter of eucalyptus (leaves and stem) and $U$. brizantha
\end{abstract}

The online version is available at http://www.springerlink.com

Corresponding editor: Zhu Hong.

Allan Lopes Bacha

allan_lb@hotmail.com

Michel Anderson Almeida Colmanetti

michelcolmanetti@gmail.com

1 University of Sao Paulo - USP/ESALQ, Avenida Pádua Dias 11, Piracicaba, SP 13418-900, Brazil

2 Sao Paulo State University - UNESP/FCAV, Via de Acesso Prof. Paulo Donato Castellane s/n, Jaboticabal, SP 14884-900, Brazil (leaves). In coexistence with 111 plants $\mathrm{m}^{-2}$, eucalyptus had reduction of $63.9 \%$ on total dry matter and $72.7 \%$ on leaf area, compared to the control. From the density of 22 plants $\mathrm{m}^{-2}, U$. brizantha negatively interfere significantly the growth of E. urograndis. Up to 8 plants $\mathrm{m}^{-2}$ there are no reductions greater than $5 \%$ in eucalyptus height and stem diameter.

Keywords Eucalyptus · Palisade grass · Competition · Interference

\section{Introduction}

Eucalyptus spp. is the most important genus for the forest sector in Brazil, being the main crop supplier of wood and cellulose (Abraf 2013). Due to investments in research of genetic improvement and development of crop management, including an effective management of weeds (Stape et al. 2004; Pereira et al. 2012), eucalyptus culture obtained an annual yield increase of $5.7 \%$ between 1970 and 2008, reaching, in 2015, $36 \mathrm{~m}^{3} \mathrm{ha}^{-1} \mathrm{a}^{-1}$ in more than 5.6 million hectares of planted area. Thus, Brazil has the eucalyptus plantations with the largest productivity in the world (Iba 2016). Although this crop is predominantly used for pulp and paper production, its consortium with forage plants is often verified in silvopastoral systems (Marques et al. 2015).

The silvopastoral system is characterized by the association of forestry and livestock activities in order to obtain a supplemental production due to the beneficial effect caused by the interaction of their components (Macedo et al. 2001). In this system, the forest species contribute to the comfort and welfare of animals, by providing shade, as well as reducing the impact of the wind and rain on the soil, 
avoiding the deterioration of pasture (Macedo 2009). It also improves the physical properties of the soil, because their roots contributes to increase the water infiltration and water holding capacity, and uses nutrients from deeper soil layers, returning them to the surface through the decomposition of leaves, branches and bark (Menezes et al. 2002).

Urochloa brizantha cv. Marandu, commom named as palisade grass, is widely recommended for grazing plantations in silvopastoral systems, due to shade tolerance (Costa et al. 2000; Ribaski and Rakocevic 2002). In order to maximize the gain in the system, the comprehension of forage plant interference on the eucalyptus initial growth is required, since it will behave as a competitor (a weed plant), resembling to the other species of Urochloa that have become weeds in eucalyptus areas in Brazil (Brendolan et al. 2000; Bacha et al. 2016).

The presence of weeds in eucalyptus areas is widely reported in the literature, which due to its competitiveness, have been a challenge in the management of different eucalyptus species (Ellis et al. 1985; Toledo et al. 2000, 2001; Adams et al. 2003; Garau et al. 2008, 2009; Cruz et al. 2010).

In addition to compete with the culture for water, nutrients, light and space, weeds can release allelochemicals into the environment, causing reduction in eucalyptus growth (Pitelli and Marchi 1991; Watt et al. 2003); or they may affect the culture indirectly, hosting pests, diseases, and increasing the risk of fire (Pitelli and Marchi 1991). In this context, several studies have been carried out in order to realize how the different species of weeds affect the different forest species (Sands and Nambiar 1984; Ellis et al. 1985; Caldwell et al. 1995; Adams et al. 2003; Florentine and Fox 2003; Schaller et al. 2003; Coll et al. 2004; Garau et al. 2008; Cruz et al. 2010; Marques et al. 2015).

Eucalyptus plants are sensitive to interference imposed by coexistence with weeds during its initial development period, which comprising from planting until about a year old (Nambiar and Sands 1993; Florentine and Fox 2003; Garau et al. 2009), as this competition can results in physiological changes that adversely affect photosynthetic characteristics of eucalyptus (Santos et al. 2015). Several factors affect the magnitude of the interference, such as: eucalyptus clone resistance to competition (Cruz et al. 2010; Pereira et al. 2013); weed plant species (Torres et al. 2010); weed density (number of weed plants per unit area) and the distance between weeds and eucalyptus plants (Dinardo et al. 2003; Graat et al. 2015; Bacha et al. 2016); and the period of coexistence between the weeds and crop (Toledo et al. 2000). The density is an essential factor to be studied, since even at low intensity $\left(4\right.$ plants $\left.\mathrm{m}^{-2}\right)$ some species of weeds lead decreasing of up $55 \%$ on the dry matter of Eucalyptus grandis stem (Toledo et al. 2001). Therefore, studies in this direction can provide important information to producers and the scientific community in order to guide the management and efficient control of species that become weeds or possible partners in production systems (Marques et al. 2015).

Assuming that high $U$. brizantha densities reduce the growth of E. urograndis, this study aimed to evaluate the interference of increasing densities of $U$. brizantha in the early development of E. urograndis.

\section{Materials and methods}

The experiment was carried out from April to July 2010, in an open and semi-controlled area located at Sao Paulo State University-UNESP/FCAV, Jaboticabal, SP, Brazil $\left(21^{\circ} 14^{\prime} 39.33^{\prime \prime} \mathrm{S} ; 48^{\circ} 17^{\prime} 56.41^{\prime \prime} \mathrm{W}\right)$. The site has altitude of 592 m, climate Cwa, according to Köppen (1948), subtropical, with rainy summer, dry winter, average annual rainfall of $1552 \mathrm{~mm}$ and average temperature of $22{ }^{\circ} \mathrm{C}$ (meteorological data in Table 1).

The experiment was conducted during 90 days after planting (DAP) of eucalyptus, and all the plants were planted in pots of $20 \mathrm{~L}$ ( $28 \mathrm{~cm}$ in diameter and $32 \mathrm{~cm}$ deep) previously filled with substrate formed by soil mixture collected in the surface layer of a red Latosol and sand in the ratio 2:1 (v/v).

Seedlings of a $E$. grandis $\times E$. urophylla (E. urograndis clone GG100) were used, which had, on average, 90 days old, $20 \mathrm{~cm}$ in height, $1.25 \mathrm{~mm}$ in diameter and 10-12 leaves.

The experiment was designed in a $6 \times 7$ factorial scheme, respectively represented by the time of measurements (fortnightly), and weeds density: 0 (control), 1, 2, 3, 4, 5 and 6 plants per pot, corresponding to a density of, respectively, $0,22,33,44,67,89$ and 111 plants $\mathrm{m}^{-2}$. A completely randomized design with four replications by treatment was used, in which each pot consisted of an experimental unit. All pots were irrigated daily until field capacity and one eucalyptus seedling was transplanted in the center of each pot.

The $U$. brizantha seedlings were obtained by sowing in trays with horticultural substrate in order to standardize the size of the weed plant, being transplanted after having two fully expanded leaves.

Ten days after eucalyptus planting, the $U$. brizantha seedlings were transplanted to the pots at a distance of $5 \mathrm{~cm}$ from the eucalyptus, according to the densities proposed for treatments.

As cultural practices, were carried out: a nitrogenous fertilizer at $10 \mathrm{DAP}$, with $50 \mathrm{~mL}$ of $2 \%$ urea solution; and a NPK fertilizer (4-14-8; $400 \mathrm{~kg} \mathrm{ha}^{-1}$ ) at 40 DAP. Due to the presence of aphids, an deltamethrin application at a dose of $5.0 \mathrm{~g} \mathrm{ha}^{-1}$ (EC Decis ${ }^{\circledR} 25-200 \mathrm{~mL} \mathrm{ha}^{-1}$ ) was also carried out at 40 DAP.

Fortnightly, until 90 DAP, the eucalyptus plants height and stem diameter were evaluated. On these occasions, 
Table 1 Monthly meteorological data of Jaboticabal-SP region, Brazil, 2010

\begin{tabular}{lllllllll}
\hline Month & Pressure $(\mathrm{hPa})$ & $\mathrm{Tmax}\left({ }^{\circ} \mathrm{C}\right)$ & $\mathrm{T} \min \left({ }^{\circ} \mathrm{C}\right)$ & $\mathrm{Tave}\left({ }^{\circ} \mathrm{C}\right)$ & $\mathrm{RH}(\%)$ & Precipitation $(\mathrm{mm})$ & $\mathrm{NRD}$ & $\mathrm{Insolation}(\mathrm{h})$ \\
\hline Apr & 944.7 & 29.2 & 17.1 & 22.2 & 74.6 & 95.5 & 07 & 245.7 \\
May & 944.9 & 27.1 & 14.1 & 19.5 & 72.5 & 10.6 & 04 & 239.9 \\
Jun & 948.0 & 27.4 & 12.0 & 18.5 & 68.3 & 7.8 & 02 & 256.1 \\
Jul & 947.8 & 29.2 & 13.9 & 20.4 & 63.8 & 0.0 & 278.9 \\
\hline
\end{tabular}

Pressure, atmospheric pressure; Tmax, average maximum temperature; Tmin, average minimum temperature; Tave, average temperature; RH, relative humidity of air; NRD, number of rainy days

were also determined, in the third fully expanded leaf from the plant apex, the fluorescence of chlorophyll $a-F_{\mathrm{v}} / F_{\mathrm{m}}$ (Hansatech, mod. PEA).

At 90 DAP, the end of experimental period, net $\mathrm{CO}_{2}$ assimilation rate $\left(\mu \mathrm{mol} \mathrm{m}{ }^{-2} \mathrm{~s}^{-1}\right)$, stomatal conductance $\left(\mathrm{mol} \mathrm{m} \mathrm{s}^{-2} \mathrm{~s}^{-1}\right)$ and transpiration rate $\left(\mathrm{mmol} \mathrm{m} \mathrm{m}^{-2} \mathrm{~s}^{-1}\right)$ were evaluated with an infrared gas analyzer (IRGA mod. LI $\left.6400, \mathrm{LiCor}^{\circledR}\right)$, in the third expanded leaf. The working reference conditions adopted for gas exchange evaluations were: $350 \mu \mathrm{mol} \mathrm{CO} \mathrm{mol}^{-1}, 9 \mathrm{mmol} \mathrm{mol}^{-1}$, the chamber temperature was set at $25^{\circ} \mathrm{C}$, atmospheric pressure in $1000 \mathrm{kPa}$, flow rate at $400 \mu \mathrm{mol} \mathrm{s}{ }^{-1}$, and the photosynthetically active radiation (PAR) at $1000 \mu \mathrm{mol} \mathrm{m} \mathrm{m}^{-2} \mathrm{~s}^{-1}$.

Also at 90 DAP, eucalyptus and weeds were cut close to the soil to leaf area determination (LiCor, mod LI 3100). Leaves and stems were dried in a forced circulation oven $\left( \pm 70{ }^{\circ} \mathrm{C}\right)$ for $96 \mathrm{~h}$ to determine the dry matter mass.

Analysis of variance was performed in $6 \times 7$ factorial scheme for stem diameter, eucalyptus height and $F_{\mathrm{v}} / F_{\mathrm{m}}$. We used the multiple regression models for the variables eucalyptus height, stem diameter and chlorophyll fluorescence $\left(F_{\mathrm{v}} / F_{\mathrm{m}}\right)$ on original scale, in order to investigate the relationship between the density and time. We use the package rsm from R (R Core Team 2017).

The eucalyptus variables: dry matter, leaf area, net $\mathrm{CO}_{2}$ assimilation rate, transpiration rate, stomatal conductance, and $U$. brizantha dry matter, were submitted to the analysis of variance by $F$-test. The analysis that showed significance was compared by Tukey test at the level of $5 \%$ of probability. All variables suffered Box-Cox transformation to obtain homoscedasticity. The SAS software (Statistical Analysis System, version 9.3) was used for data analysis.

\section{Results}

The eucalyptus height, stem diameter and chlorophyll fluorescence $\left(F_{\mathrm{v}} / F_{\mathrm{m}}\right)$, had significant interaction between the periods of coexistence and the densities of the forage plant (Table 2).
The eucalyptus height increased over the time, regardless of weed density (Fig. 1). From the 70 DAP on, there was noted an interference of higher weed densities compared to the densities less than 8 plants $\mathrm{m}^{-2}$.

At 90 DAP, the average height of the eucalyptus seedlings that coexisted with 78 plants $\mathrm{m}^{-2}$ or more, was $12.3 \%$ lower than plants with 8 plants $\mathrm{m}^{-2}$ or less. Also, up to 8 plants $\mathrm{m}^{-2}$, it was observed no reduced height growth greater than $5 \%$ when compared to the control (Fig. 1).

Table 2 Results of analysis of variance for Urochloa brizantha cv. Marandu densities and periods of coexistence on Eucalyptus urograndis height $(\mathrm{cm})$, stem diameter $(\mathrm{mm})$ and chlorophyll fluorescence $\left(F_{\mathrm{v}} / F_{\mathrm{m}}\right)$

\begin{tabular}{|c|c|c|c|}
\hline & Height $(\mathrm{cm})$ & Diameter (mm) & $F_{\mathrm{v}} / F_{\mathrm{m}}$ \\
\hline \multicolumn{4}{|c|}{ Periods of coexistence (days) } \\
\hline 15 & $45.71 \mathrm{E}$ & $3.59 \mathrm{E}$ & $0.791 \mathrm{AB}$ \\
\hline 30 & $50.32 \mathrm{D}$ & $4.68 \mathrm{D}$ & $0.721 \mathrm{C}$ \\
\hline 45 & $56.37 \mathrm{C}$ & $5.60 \mathrm{C}$ & $0.768 \mathrm{~B}$ \\
\hline 60 & $60.62 \mathrm{~B}$ & $7.07 \mathrm{~B}$ & $0.700 \mathrm{C}$ \\
\hline 75 & $65.39 \mathrm{~A}$ & $8.61 \mathrm{~A}$ & $0.707 \mathrm{C}$ \\
\hline 90 & $66.23 \mathrm{~A}$ & $9.17 \mathrm{~A}$ & $0.815 \mathrm{~A}$ \\
\hline \multicolumn{4}{|l|}{ Densities (plants $\mathrm{m}^{-2}$ ) } \\
\hline 0 & $60.35 \mathrm{~A}$ & $7.24 \mathrm{~A}$ & $0.771 \mathrm{~A}$ \\
\hline 22 & $59.12 \mathrm{AB}$ & $7.18 \mathrm{~A}$ & $0.765 \mathrm{~A}$ \\
\hline 33 & $56.14 \mathrm{C}$ & $6.40 \mathrm{BC}$ & $0.738 \mathrm{AB}$ \\
\hline 44 & $53.35 \mathrm{D}$ & $5.92 \mathrm{C}$ & $0.746 \mathrm{AB}$ \\
\hline 67 & $58.54 \mathrm{ABC}$ & $6.41 \mathrm{~B}$ & $0.747 \mathrm{AB}$ \\
\hline 89 & $56.97 \mathrm{BC}$ & $5.99 \mathrm{BC}$ & $0.729 \mathrm{~B}$ \\
\hline 111 & $57.67 \mathrm{ABC}$ & $6.03 \mathrm{BC}$ & $0.715 \mathrm{~B}$ \\
\hline F periods & $193.28 * *$ & $551.49 * *$ & $34.74 * *$ \\
\hline F densities & $12.69 * *$ & $16.23 * *$ & $4.12 * *$ \\
\hline F periods $\times$ densities & $2.07 * *$ & $3.15 * *$ & $1.69 * *$ \\
\hline CV (\%) & 5.50 & 4.51 & 5.20 \\
\hline
\end{tabular}

Means followed by the same letter do not differ from each other by Tukey test at $5 \%$ of probability. **Significant values at $1 \%$ of probability by the $F$-test. $\mathrm{CV}$ is coefficient of variation. $\mathrm{F}$ is $F$-test value 


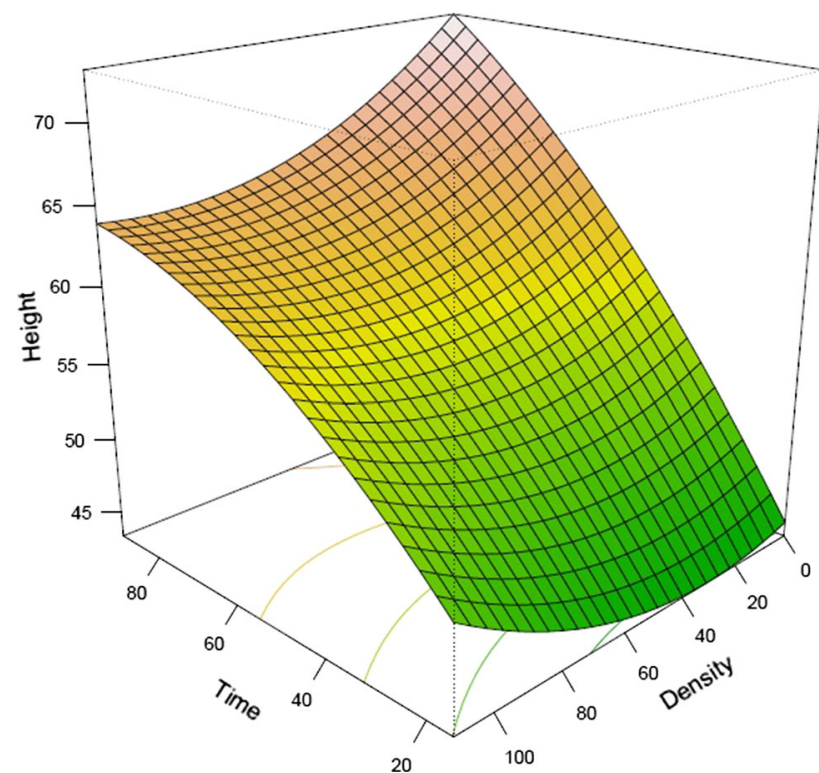

Fig. 1 Effect of increasing densities of Urochloa brizantha cv. Marandu on Eucalyptus urograndis (clone GG100) height $(\mathrm{cm})$ during 90 days after planting. Height $=35.9+0.5$. Time -0.03 . Dens $-0.002 \cdot$ Time $\times$ Dens $-0.002 \cdot$ Time $^{2}+0.001 \cdot$ Dens $^{2}$

After 90 days, the highest stem diameter values were observed at the lowest densities (from the control to about 8 plants $\mathrm{m}^{-2}$ ) (Fig. 2). Furthermore, the values of stem diameter at 75 DAP in the control treatment, was similar to 78 plants $\mathrm{m}^{-2}$ at 90 DAP, evidencing the stem diameter interference due to environmental resources competition.

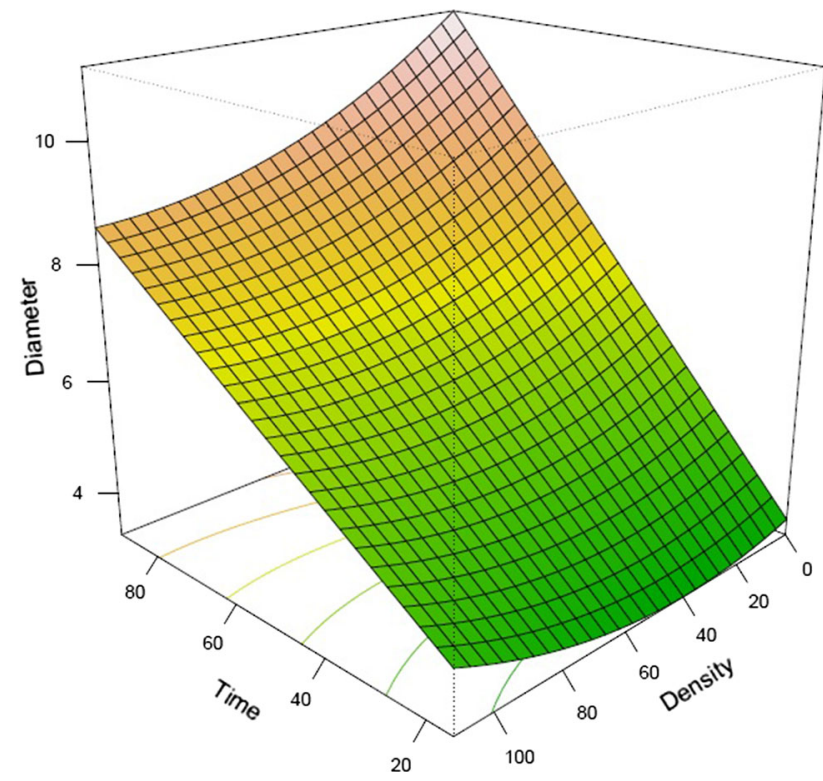

Fig. 2 Effect of increasing densities of Urochloa brizantha cv. Marandu on Eucalyptus urograndis (clone GG100) diameter (mm) during 90 days after planting. Diameter $=1.9+0.1 \cdot$ Time -0.009 . Dens $-4 \cdot e^{4} \cdot$ Time $\times$ Dens $-8.8 \cdot e^{6} \cdot$ Time $^{2}+2 \cdot e^{4} \cdot$ Dens $^{2}$
At 90 DAP, the average diameter of the eucalyptus that coexisted in 78 plants $\mathrm{m}^{-2}$ or more, was $18.7 \%$ lower than the diameter in density smaller than 8 plants $\mathrm{m}^{-2}$. Also, up to 12 plants $\mathrm{m}^{-2}$, it was observed no reduced diameter growth greater than 5\% when compared to the control (Fig. 2).

Regarding the quantum efficiency of photosystem II (PSII) $\left(F_{\mathrm{v}} / F_{\mathrm{m}}\right)$, the response pattern was the same in relation to time (Fig. 3). There was a decrease in values in relation to density, where the lowest densities had the highest values, and the highest densities had lowest values.

At the end of the experimental period, the treatment with the highest density was $5.2 \%$ lower than the control. Thus, among the variables evaluated during the experiment, the $F_{\mathrm{v}} / F_{\mathrm{m}}$ was the variable with less sensitive to the stress due to competition with the weed (Fig. 3).

Concerning the eucalyptus dry matter (Table 3), all plants that coexisted with $U$. brizantha showed lower values compared to the control. It should be noted that treatment with 22 plants $\mathrm{m}^{-2}$ also differed from the treatments with 44,89 and 111 plants $\mathrm{m}^{-2}$; and the eucalyptus plants that coexisted with the highest density of $U$. brizantha showed $63.9 \%$ less dry matter compared to control. For the leaf area (Table 3), all treatments, except that with 22 plants $\mathrm{m}^{-2}$, were significantly different from control, with lower values for this variable. Treatments with 22 and 33 plants $\mathrm{m}^{-2}$ did not differed from each other, but showed statistical difference for the treatments with 44,89 and 111 plants $\mathrm{m}^{-2}$. Also, the treatment with the highest density of weed plant resulted in lower leaf area, being $72.7 \%$

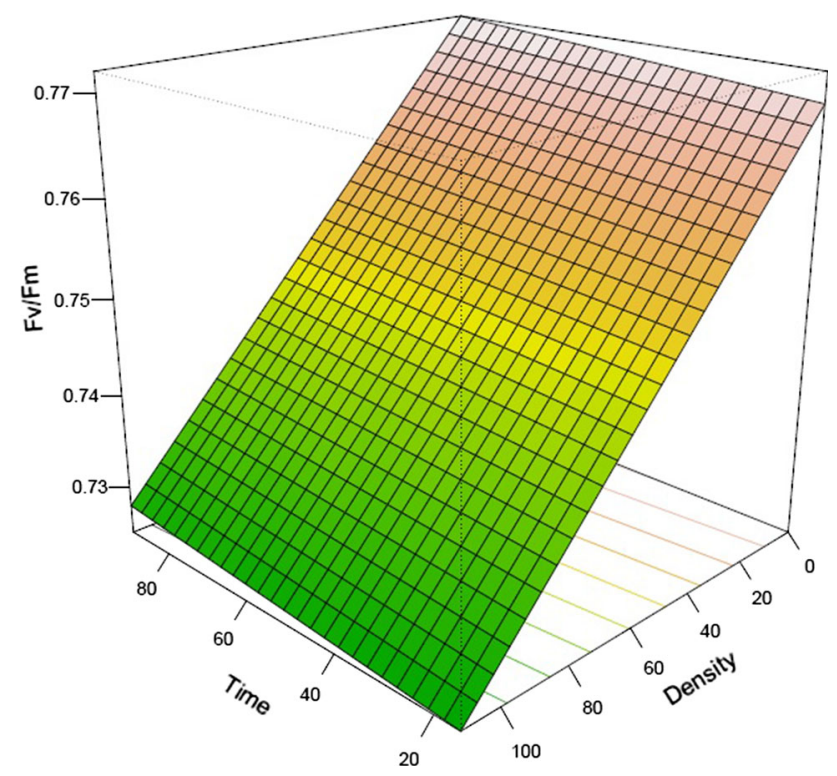

Fig. 3 Effect of increasing densities of Urochloa brizantha cv. Marandu on Eucalyptus urograndis (clone GG100) $F_{\mathrm{v}} / F_{\mathrm{m}}$ during 90 days after planting. $\frac{F v}{F m}=0.76+0.00004 \cdot$ Time $-0.0004 \cdot$ Dens 
Table 3 Average values of variables: Eucalyptus urograndis (clone GG100) dry matter (DMeuc-g), leaf area, net $\mathrm{CO}_{2}$ assimilation rate $\left(\mu \mathrm{mol} \mathrm{m} \mathrm{m}^{-2} \mathrm{~s}^{-1}\right)$, stomatal conductance $\left(\mathrm{mol} \mathrm{m}^{-2} \mathrm{~s}^{-1}\right)$, transpiration

\begin{tabular}{|c|c|c|c|c|c|c|}
\hline $\begin{array}{l}\text { Densities } \\
\left(\text { plants } \mathrm{m}^{-2} \text { ) }\right.\end{array}$ & $\begin{array}{l}\text { DMeuc } \\
(\mathrm{g})\end{array}$ & $\begin{array}{l}\text { Leaf area } \\
\left(\mathrm{cm}^{2}\right)\end{array}$ & $\begin{array}{l}\mathrm{Net} \mathrm{CO}_{2} \\
\text { assimilation rate }\end{array}$ & $\begin{array}{l}\text { Stomatal } \\
\text { conductance }\end{array}$ & $\begin{array}{l}\text { Transpiration } \\
\text { rate }\end{array}$ & $\begin{array}{l}\text { DMpalisade } \\
\text { grass }(\mathrm{g})\end{array}$ \\
\hline 0 & $45.05 \mathrm{~A}$ & $3256.4 \mathrm{~A}$ & 10.50 & 0.0822 & 1.56 & - \\
\hline 22 & $33.46 \mathrm{~B}$ & $2151.9 \mathrm{AB}$ & 10.15 & 0.1223 & 2.19 & $11.43 \mathrm{~A}$ \\
\hline 33 & $26.25 \mathrm{BC}$ & $1713.3 \mathrm{~B}$ & 8.41 & 0.1091 & 1.96 & $9.78 \mathrm{AB}$ \\
\hline 44 & $17.11 \mathrm{C}$ & $972.4 \mathrm{C}$ & 9.22 & 0.1388 & 2.48 & $8.98 \mathrm{AB}$ \\
\hline 67 & $23.22 \mathrm{BC}$ & $1429.5 \mathrm{BC}$ & 12.27 & 0.1600 & 2.75 & $6.25 \mathrm{ABC}$ \\
\hline 89 & $17.07 \mathrm{C}$ & $948.7 \mathrm{C}$ & 9.16 & 0.1398 & 2.47 & $5.37 \mathrm{BC}$ \\
\hline 111 & $16.26 \mathrm{C}$ & $887.8 \mathrm{C}$ & 10.11 & 0.1508 & 2.63 & $3.89 \mathrm{C}$ \\
\hline $\mathrm{F}$ & $21.13 * *$ & $21.70 * *$ & $1.19^{\mathrm{ns}}$ & $1.63^{\mathrm{ns}}$ & $1.90^{\mathrm{ns}}$ & $5.84 * *$ \\
\hline
\end{tabular}

Average of $U$. brizantha dry matter (DMpalisade grass-grams per plant unity)

Means followed by different letters differ from each other at the level of $5 \%$ of probability by Tukey test. **Significant at the level of $1 \%$ of probability. ${ }^{\text {ns }}$ Not significant by $F$-test

lower than control, proving to be the most sensitive variable to the competition imposed by $U$. brizantha.

In the assessments of net $\mathrm{CO}_{2}$ assimilation rate, stomatal conductance and transpiration rate of eucalyptus, held at 90 DAP (Table 3), there were no significant differences between treatments.

For $U$. brizantha dry matter (Table 3 ), it was observed that with increasing densities per treatment, there was a decrease of the mean values of this variable per unit of $U$. brizantha, in which the treatment with 22 plants $\mathrm{m}^{-2}$ differ significantly than that with 89 and 111 plants $\mathrm{m}^{-2}$, and the densities of 33 and 44 plants $\mathrm{m}^{-2}$ had statistical difference for treatment with higher density, which showed dry matter value $65.9 \%$ lower than the treatment of lower density (22 plants $\mathrm{m}^{-2}$ ).

\section{Discussion}

The reduced development of some eucalyptus variable, such as plants height, stem diameter, dry matter, leaf area and quantum efficiency of PSII $\left(F_{\mathrm{v}} / F_{\mathrm{m}}\right)$ (Figs. 1, 2, 3; Table 3), which were observed in this study, is the result of interference imposed by $U$. brizantha plants to the eucalyptus and corroborate results obtained by many authors (Toledo et al. 2000; Adams et al. 2003; Florentine and Fox 2003; Garau et al. 2009). They elucidate that the first year after crop installation is the period in which eucalyptus are more susceptible to competition imposed by weeds. Based on a field experiment, Tarouco et al. (2009) observed that if E. urograndis plants were free of competition for a total period of 335 DAP, there would be no significant loss of productivity due to interference of weeds in the crop. The rate $\left(\mathrm{mmol} \mathrm{m} \mathrm{m}^{-2} \mathrm{~s}^{-1}\right)$, after 90 days of coexistence with increasing densities of Urochloa brizantha cv. Marandu 
eucalyptus, causing deficiencies that result in changes of some parameters related to photosynthesis, like low quality and/or amount of incident light (Sharkey and Raschke 1981) and water deficiency (Margolis and Brand 1990; Grossnickle and Folk 1993; Lamhamedi et al. 1998).

The quantum efficiency of PSII, which is represented by the fluorescence ratio $F_{\mathrm{v}} / F_{\mathrm{m}}$, is an important physiological characteristic used in studies related to different stresses (for example, the one caused by competition with weeds), because it is an indicator of the photosynthetic capacity of the plants. These values express the efficient capture of light energy by the PSII reaction center, resulting in an electron transport through this photosystem (Krause and Weis 1991).

Maxwell and Johnson (2000) emphasized that the optimal values of $F_{\mathrm{v}} / F_{\mathrm{m}}$ can vary across species. Based on this study we clearly observed the $F_{\mathrm{v}} / F_{\mathrm{m}}$ reduction according to weed density increasing (Fig. 3). We speculate that the low values of $F_{\mathrm{v}} / F_{\mathrm{m}}$, which was found in the treatments with the highest densities of $U$. brizantha, was the cause of the decrease in the values of the other characteristics evaluated in this study, since the photoassimilates produced on photosynthesis are used in plant growth. Also, as the gas exchange evaluations (transpiration, stomatal conductance and net $\mathrm{CO}_{2}$ assimilation rate) did not indicate difference between the treatments (Table 3), we can infer that the limitation of the process was found in the photochemical phase of photosynthesis (indicated by the $F_{\mathrm{v}} / F_{\mathrm{m}}$ ratio).

Regarding U. brizantha dry matter (Table 3 ), it is possible to observe that the larger the number of plants per unit area, smaller was the individual growth of the plants. Thus, it is evident that the competition for the environmental resources was a limiting factor for the plants growth in both occasions, to the culture (in a interspecific competition) and to the weed community (in a intraspecific competition).

\section{Conclusion}

We conclude that from the density of 22 plants $\mathrm{m}^{-2}$, Urochloa brizantha cv. Marandu negatively interferes in the growth of Eucalyptus urograndis (clone GG100). Up to 8 plants $\mathrm{m}^{-2}$ there are no reductions greater than $5 \%$ in eucalyptus height and stem diameter.

Acknowledgements The authors would like to thank all members of the Weed Sciences Laboratory of UNESP (LAPDA) for their support in this study.

\section{References}

Abraf (2013) Associação brasileira dos produtores de florestas plantadas. Anuário estatístico da abraf, ano base 2012. http:// www.ipef.br/estatisticas/relatorios/anuario-ABRAF13-BR.pdf. Accessed 25 Feb 2017

Adams PR, Beadle CL, Mendham NJ, Smethurst PJ (2003) The impact of timing and duration of grass control on the growth of a young Eucalyptus globulus Labill. plantation. New For 26(2):147-165

Bacha AL, Pereira FCM, Pires RN, Nepomuceno MP, Alves PLCA (2016) Interference of seeding and regrowth of signalgrass weed (Urochloa decumbens) during the initial development of Eucalyptus urograndis $(E$. grandis $\times E$. urophylla). Aust J Crop Sci 10(3):322-330

Bleasdale JKA (1960) Studies on plant competition. In: Harper JL (ed) The biology of weeds. Blackwell Scientific Publications, Oxford, pp 133-142

Brendolan RA, Pellegrini MT, Alves PLCA (2000) Efeitos da nutrição mineral na competição inter e intraespecífica de Eucalyptus grandis e Brachiaria decumbens: 1-crescimento. Sci For 58:49-57

Caldwell JM, Sucoff EI, Dixon RK (1995) Grass interference limits resource availability and reduces growth of juvenile red pine in the field. New For 10(1):1-15

Coll L, Balandier P, Picon-Cochard C (2004) Morphological and physiological responses of beech (Fagus sylvatica) seedlings to grass-induced belowground competition. Tree Physiol 24(1):45-54

Costa NL, Townsend CR, Magalhães JA, Pereira RGA (2000) Desempenho agronômico de gramíneas forrageiras sob sombreamento de eucalipto (Eucalyptus spp.). Embrapa Cpaf Rondônia 184:1-4

Cruz MB, Alves PLCA, Karam D, Ferraudo AS (2010) Capimcolonião e seus efeitos sobre o crescimento inicial de clones de Eucalyptus $x$ urograndis. Cienc Florest 20(3):391-401

Dinardo W, Toledo REB, Alves PLCA, Pitelli RA (2003) Efeito da densidade de plantas de Panicum maximum Jacq. sobre o crescimento inicial de Eucalyptus grandis W. Hill ex Maiden. Sci For 64:59-68

Ellis RC, Webb DP, Graley AM, Rout AF (1985) The effect of weed competition and nitrogen nutrition on the growth of seedlings of Eucalyptus delegatensis in a highland area of Tasmania. Aust For Res 15(4):395-408

Florentine S, Fox J (2003) Competition between Eucalyptus victrix seedlings and grass species. Ecol Res 18(1):25-39

Garau AM, Lemcoff JH, Ghersa CM, Beadle CL (2008) Water stress tolerance in Eucalyptus globulus Labill. subsp. maidenii (F. Muell.) saplings induced by water restrictions imposed by weeds. For Ecol Manag 255(7):2811-2819

Garau AM, Lemcoff JH, Ghersa CM, Barañao JJ (2009) Weeds in Eucalyptus globulus subsp. maidenii (F. Muell) establishment: effects of competition on sapling growth and survivorship. New For 37(3):251-264

Graat Y, Rosa JO, Nepomuceno MP, Carvalho LB, Alves PLCA (2015) Grass weeds interfering with eucalypt: effects of the distance of coexistence on the initial plant growth. Planta Daninha 33(2):203-211

Grossnickle S, Folk R (1993) Stock quality assessment: forecasting survival and performance on a reforestation niche. Tree Plant Notes 44(3): 113-121

Iba (2016) Indústria brasileira de árvores. Relatório IBÁ 2016. http:// iba.org/images/shared/Biblioteca/IBA_RelatorioAnual2016_. pdf. Accessed 23 Feb 2017 
Köppen W (1948) Climatologia: con un estudio de los climas de la tierra. Fondo de Cultura Econômica, Mexico City, p 478

Krause GH, Weis E (1991) Chlorophyll fluorescence and photosynthesis: the basics. Annu Rev Plant Phys 42(2):313-349

Lamhamedi M, Bernier P, Hebert C, Jobidon R (1998) Physiological and growth responses of three sizes of containerized Picea mariana seedlings outplanted with and without vegetation control. For Ecol Manag 110(1-3):13-23

Macedo MCM (2009) Integração lavoura pecuária: o estado da arte e inovação tecnológicas. Rev Bras Zootech 38(1):133-146

Macedo RIG, Venturim N, Gomes JE, Lima EMG (2001) Princípios de agrossilvicultura como subsídios do manejo sustentável. Informe Agropecuário 29(1):15-26

Margolis HA, Brand DG (1990) An ecophysiological basis for understanding plantation establishment. Can J For Res 20(4):375-390

Marques DB, Martins PFRB, Parreira MC, Alves PLCA (2015) Companion crops upon Eucalyptus urograndis initial development. Bosque 36(2):163-170

Maxwell K, Johnson GN (2000) Chlorophyll fluorescence: a practical guide. J Exp Bot 51:659-668

Menezes RSC, Salcedo IH, Elliott ET (2002) Microclimate and nutrient dynamic in a silvopastoral system of semiarid northeastern Brazil. Agrofor Syst 56(1):27-38

Nambiar EKS, Sands R (1993) Competition for water and nutrients in forests. Can J For Res 23(10):1955-1968

Pereira FCM, Yamauti MS, Alves PLCA (2012) Interaction between weed management and covering fertilization in the initial growth of Eucalyptus grandis $\times$ E. urophylla. Rev Árvore 36(5):941-949

Pereira FCM, Alves PLCA, Martins JVF (2013) Interference of grasses on the growth of eucalyptus clones. J Agric Sci 5(11): $173-180$

Pitelli RA (1985) Interferência das plantas daninhas em culturas agrícolas. Informe Agropecuário 11(129):16-27

Pitelli RA, Marchi SR (1991) Interferência das plantas invasoras nas áreas de reflorestamento. Seminário Técnico Sobre Plantas Daninhas e o Uso de Herbicidas em Reflorestamento 3:1-11

R Development Core Team (2017) R: a language and environment for statistical computing. R Foundation for Statistical Computing, Vienna, Austria. http://www.R-project.org
Ribaski J, Rakocevic M (2002) Disponibilidade e qualidade da forragem de braquiária (Brachiaria brizantha) em um sistema silvipastoril com eucalipto (Eucalyptus citriodora) no noroeste do Estado do Paraná. Congresso brasileiro de sistemas agroflorestais, Ilhéus. https://www.alice.cnptia.embrapa.br/bitstream/ doc/307621/1/6026disponibilidade.pdf. Accessed 08 Feb 2017

Sands R, Nambiar EKS (1984) Water relations of Pinus radiata in competition with weeds. Can J For Res 14(2):233-237

Santos MV, Ferreira EA, Tuffi Santos LD, Fonseca DM, Aspiazu I, Silva DV, Porto JMP, Braga RR (2015) Physiological aspects of acacia and eucalyptus in competition with Brachiaria. Aust $\mathbf{J}$ Crop Sci 9(3):210-214

Schaller M, Schroth G, Beer J, Jiménez F (2003) Root interactions between young Eucalyptus deglupta trees and competitive grass species in contour strips. For Ecol Manag 179(1-3):429-440

Sharkey TD, Raschke K (1981) Effect of light quality on stomatal opening in leaves of Xanthium strumarium L. Plant Physiol 68(5): 1170-1174

Stape J, Binkley D, Ryan MG, Gomes AN (2004) Water use, water limitation, and water use efficiency in a eucalyptus plantation. Bosque 25(2):35-41

Tarouco CP, Agostinetto D, Panozzo LE, Santos LS, Vignolo GK, Ramos LOO (2009) Períodos de interferência de plantas daninhas na fase inicial de crescimento do eucalipto. Pesqui Agropecu Bras 44(9):1131-1137

Toledo REB, Victoria Filho R, Pitelli RA, Alves PLCA, Lopes MAF (2000) Efeitos de períodos de controle de plantas daninhas sobre o desenvolvimento inicial de plantas de eucalipto. Planta Daninha 18(3):395-404

Toledo REB, Dinardo W, Bezutte AJ, Alves PLCA, Pitelli RA (2001) Efeito da densidade de plantas de Brachiaria decumbens Stapf sobre o crescimento inicial de mudas de Eucalyptus grandis W. Hill ex Maiden. Sci For 60:109-117

Torres LG, Faria AT, Felipe RS, Benevenute SS, Medeiros WN, Ferreira FA (2010) Interferência de plantas daninhas sobre o crescimento inicial de mudas de clones de eucalipto. Congresso Brasileiro da Ciência das Plantas Daninhas 28:105-109

Watt MS, Whitehead D, Mason EG, Richardson B, Kimberley MO (2003) The influence of weed competition for light and water on growth and dry matter partitioning of young Pinus radiata, at a dryland site. For Ecol Manag 183(1-3):363-376 